\title{
Hegel and the justification of real-world penal sanctions*
}

\author{
Antje du Bois-Pedain
}

\begin{abstract}
This article revisits Hegel's writings on punishment to reconstruct from them a justification for the imposition of real-world penal sanctions. Tracing Hegel's argumentative path from a bare retributive principle to his mature justification of state punishment, it argues that Hegel offers us convincing reasons for endorsing, in broad shape, the distinctive penal institutions and practices of a modern nation-state. Hegel is also right to stress that punishment is - not merely conceptually, but also in the reality of our social world - a recognition of an offender's status as a bearer of rights and participant in a system of mutual recognition that allows us to collectively build and maintain an order of freedom. This understanding of punishment sets significant limits to punishment's permissible forms, particularly - but not only - with regard to the death penalty. By focusing on what it means to honour an offender through punishment and by drawing attention to what legal punishment has in common with reactions to transgressions by the will more generally, I question whether the infliction of penal suffering can, as such, be a legitimate aim of penal agents. In conclusion, I argue that only a commitment to penal minimalism, developable from Hegel's thought, can give those subjected to realworld penal sanctions a complete answer to the question why they should accept their punishment as justified.
\end{abstract}

\section{Introduction}

Hegel's views on punishment have retained the attention of legal philosophers for nearly two centuries. Much of this fascination is due to Hegel's apparent answer to what J.L. Mackie has called the paradox of retribution: that, "on the one hand, a retributive principle of punishment cannot be explained or developed within a reasonable system of moral thought, while, on the other hand, such a principle cannot be eliminated from our moral thinking”. ${ }^{1}$ Discussions of Hegel's theory of punishment thus frequently focus on his claim that punishment cancels or annuls the crime. ${ }^{2}$ These discussions, while helpful in working through the concept of retribution, risk reducing Hegel's theory of punishment to just one element within it. Unlike philosophers whose project consists in justifying their retributive intuitions, Hegel himself was concerned with a different task: to explicate and justify the key features of the penal practices of modern states. Since the state is, for Hegel, the framework through which human freedom in its fullest sense is made possible and realised, this task for him necessarily involves a philosophical demonstration of the compatibility of state punishment with the offender's freedom.

* This is the accepted version of a paper accepted for publication in the Canadian Journal of Law and Jurisprudence (forthcoming 2016). Earlier versions of this paper were discussed at the LSE's Criminal Law and Criminal Justice Forum and at an ALPP-UK meeting in London in the autumn of 2015. An embryonic version was presented at a MANCEPT workshop on "Punishment and Legitimacy" in September 2013. I thank the respective organisers, Emmanuel Melissaris, Matthew Kramer and Richard Child, for inviting me to present my work on these occasions. I also thank the participants for their incisive questions and comments that helped me to clarify my argument, including Peter Ramsay, Miriam Gur-Arye, Jeremy Horder, Matthew Kramer, Matt Matravers, Mark Reiff, Amit Pundik, David Miller, Sandy Steel, Richard Child, Jules Holroyd, and Chris Bennett. I also thank Liat Levanon for our long discussion of Bernstein's work, which has greatly influenced section IV of the paper.

${ }^{1}$ Mackie 1982, p. 3. Definitions of retributivism vary. I use the term as designating the view that one ought to punish an offender simply because such punishment is called for, and deserved, as a response to his crime, quite irrespective of any positive effects of his punishment.

2 See, eg Anderson 1999, and the examples given by Brooks 2004, note 1. 
But is state punishment, as we know it, indeed compatible with the punished offender's freedom? In her attack on Alan Brudner's reworking and defense of Hegel's argumentative moves, ${ }^{3}$ Alice Ristroph suggests that Hegel's arguments amount to abject failures: in Ristroph's estimation, Hegel fails to offer real-world criminals any reason to accept their punishment as self-willed, and - what is worse - he completely fails to account for punishment's real-life dimension as a form of violence against the body. ${ }^{4}$

This article pursues the question whether Hegel's theory can provide an offender with sufficient reasons to accept the imposition of a real-life penal sanction. In answering this question, I focus on the two aspects of Hegel's theory Ristroph attacks: the notion that reallife offenders can in some significant sense be said to have willed their own punishment, and - given that "willing one's own punishment" is not "willing one's own ill-treatment" - the form that such punishment may take.

The argument proceeds as follows: Section II traces the main argumentative steps in Hegel's development of state punishment, and argues that Hegel succeeds in capturing the evolutionary ethical necessity of punishment's institutionalisation in social practices that strongly resemble the penal institutions of a modern nation-state. At the same time, it remains doubtful whether Hegel can, as he claims, indeed demonstrate on the basis of his arguments that punishment is also justified "subjectively", i.e. vis-à-vis the offender, as an emanation of his own true freedom. The difficulties with Hegel's "subjective" justification ${ }^{5}$ of punishment are addressed in Section III, which unpacks Hegel's claim that punishment is true to, and selfimposed by, the offender's rational will. It argues that the best way to defend this claim is to interpret punishment as constituting a recognition of the offender as a moral person through moral censure - but that this very answer also shows the true force behind the second objection, in that the imposition of suffering and a (censuring) recognition of personhood may not sit comfortably together. Section IV therefore turns to the question how Hegel's theory might account for, and restrain the imposition of, penal suffering. The first point I make here is that Hegel requires punishment to be a hardship. But what kind of hardship? May punishment set out to make the penal subject suffer? If we turn our attention to what crime and punishment have in common with responding to transgressions by the will more generally, we may doubt that this is the case. A consideration of what punishment means for the penalising agent provides the connection to the final section of the paper, where I develop the view that, in order to incorporate penal hard treatment appropriately into a Hegelian account of criminal justice, we must conceptualise the duty to accept one's punishment in the sphere of ethical life as a political duty. Understood along these lines, Hegel's justification of

\footnotetext{
${ }^{3}$ See Brudner 2009.

${ }^{4}$ Ristroph 2011, esp. pp. 469-472. The criticism that Hegel's justification of punishment doesn't hold water in a world in which "criminal punishment ... has devastating impacts on families and communities" and in which "no one wants to be locked up" (Ristroph, p. 469) is far from new (for similar arguments, see, eg, Flechtheim 1975). Köhler points out that some of this criticism is easily deflected by relying on Hegel's right of subjectivity, which contains the argumentative resources to reject subjectivity-destroying punishments (see also section IV below). He then contends that a sustainable challenge to Hegel's core justification of punishment as self-willed in the context of an order of freedom constituted by a system of mutual recognition, would have to rely on and develop the notion of alienation. The argument would have to be that (many) real life criminals stand outside the system of mutual recognition such that a justification of punishment that relies on their membership in that system does not address them at all. (See Köhler 1987, pp. 13-14).

${ }^{5}$ The labels “objective” and "subjective” justification of punishment are widely used in the discussion of Hegel's theory of punishment. In this usage, punishment's "objective” justification relates to the notion that punishment is needed to manifest the nullity of the crime, and hence to uphold a system of right. Punishment's "subjective" justification is its justification, in relation to the offender's freedom, as willed by him. See Flechtheim 1963, 17; Primoratz 1989, pp. 71-78).
} 
punishment points beyond a socially embedded retributive principle towards an endorsement of penal minimalism.

Occasionally Hegel's views are still dismissed as obscurantist and unhelpful. ${ }^{6}$ But whatever the quality of his answers, it cannot be in doubt that Hegel asks the right questions. Hegel sees with admirable clarity that the task of justifying the penal practices of a modern nation-state is the task of justifying a political institution: we have to account for the machinery of law and law enforcement as political practices of our collective ethical life. Hegel also sees that, in order to justify punishment vis-à-vis the offender, we have to be able to explain to the offender why his punishment is compatible with respect for, and acknowledgement of, his status as a free human being and co-citizen. ${ }^{7}$ It is because Hegel asks the right questions that this article seeks to understand Hegel's answers and develops them beyond Hegel's own exposition where this is needed for a more satisfactory account.

\section{The justification of punishment in the Philosophy of Right}

This section revisits Hegel's writings on punishment in order to clarify two important issues: how can we account for the role of the state in punishment, and what legitimates the imposition of a penal sanction from the offender's point of view? Note that both Hegel's "objective" argument of punishment manifesting the nullity of crime, and his "subjective" linking of punishment's justification to the offender's rational will, may have to be drawn upon in order to answer each of the questions posed here as separate questions. It is not necessarily the case that the "objective" justification alone can account for the state's role in punishment; nor may it suffice for the justification of punishment vis-à-vis the offender that his punishment is "self-willed" in the sense of Hegel's "subjective" justification of punishment. $^{8}$

Since this article assumes no familiarity on the part of the reader with Hegel's work, a few remarks on Hegel's project, method and terminology are in order.

\section{Hegel's project, methodology and terminology}

Hegel defines philosophy's project as "a thinking consideration of objects"; ${ }^{9}$ a project he pursues with a distinctive speculative method that (as Thom Brooks explains) builds up the

\footnotetext{
${ }_{7}^{6}$ Eg, Honderich 1976, p. 45.

${ }^{7}$ These are equally the starting points for Brudner's Hegelian reconstruction and justification of penal law: see Brudner 2009, p. 2 and pp. 15-16.

${ }^{8}$ A different question is whether Hegel even needs to provide both an objective and a subjective justification. Jakobs 2003, p. 262, suggests that an "objective justification” of punishment takes priority, obviating the need to provide a separate "subjective justification", which must in any event be subordinate to an objective one since: "How could a punishment that is not already legitimated on some other ground, be legitimated by dint of being 'willed’ by the criminal himself?” (my translation). Norrie 1991 takes the opposite view that the subjective justification takes priority: "punishment of the individual is justified by reference to the individual, and not some extraneous source (society in general, the rights of others)" (p. 65) and it is "from the point of view of the criminal [that] it is necessary to annul the wrong” (p. 75, emphasis original) - though he later clarifies that the justification of state punishment must introduce further elements, since "State punishment entails not only that the criminal is put to rights with himself, but also that the laws of the state ... are ... re-affirmed”, such that "State punishment unifies both social and individual right and is both subjectively and objectively just” (p. 76). Merle 2009, p. 115, also questions whether Hegel needs to provide both an objective and a subjective justification of punishment.

${ }^{9}$ Hegel 1830/1991, §2 (p. 24). (I follow general usage in citing Hegel’s work with reference to the paragraph numbers of his exposition.)
} 
analysis from minimal presuppositions. ${ }^{10}$ We start at a low level of complexity (which is, at the same time, a high level of abstraction) and it is only when this analysis leads us into contradiction that we move to the next level of analysis where the elements that get us past our earlier impasse are added in. At each level, the objective of our quest is to identify and incorporate into our theory what is essential or necessary for the object and its comprehension, and to cast aside as irrelevant for the object's comprehension what is ephemeral or transient. The former is what Hegel refers to as "true" or "actual"; the latter is what he refers to as "semblance" or "mere existence". "Actuality", we might then say, is a feature of something that is, and is as it should be (and which is, therefore, enduring and stable) - whereas "mere existence" is a feature of something that is, but only by way of an intermediate stage towards what should be (and which is, therefore, ephemeral and transient). ${ }^{11}$ The ideal shape of human institutions is the shape that these institutions must, in due course, evolve in their progression towards the realisation (or "actualisation") of human freedom. $^{12}$

In line with these presuppositions, the Philosophy of Right $(P R)^{13}$ aspires to understand how human freedom becomes a reality in the progressive development of our social and political structures. The exposition leads through three main stages or frameworks: “Abstract Right”, "Morality" and "Ethical Life". As Brudner explains, Hegel's "basic idea is that [when moving from one framework to the next, earlier-stage] frameworks based on an inadequate conception of freedom are cancelled insofar as they claim to be ... exhaustive ..., but they are nonetheless preserved as instances or reflections of the most comprehensive conception [of freedom], which requires them for its own validation." ${ }^{14}$ As we move from Abstract Right through Morality to Ethical Life in our quest to understand how freedom manifests itself in the world, we develop a deeper and richer grasp of the phenomena that make up the common social world in which we, as individual human beings, can achieve our capacity for selfdetermination. ${ }^{15}$

\footnotetext{
${ }^{10}$ Brooks 2007, p. 16. In what follows, I draw heavily on Brooks' explanation of Hegel's philosophical method in Brooks 2007, Ch. 1. For a fuller description of Hegel's method, see Angehrn 1977.

${ }^{11}$ Hegel would probably put this point slightly differently, avoiding the "should" and replacing it with "must" (compare, for instance, Hegel's formulation, in Hegel 1817-18/1995, §134 (p. 242), that the rational "must come about”). This has to do with Hegel's particular notion of the "ought”, which can be described as a conception of normative necessity. Again, this is connected to Hegel's conception of philosophical task and method; as Schild explains, Hegel sets out to "understand the practice which comes before the theoretical construction, and on which the theory builds" and thus develops the kind of "theory that does not see itself as the final word on an issue but as providing a theoretically informed grasp of practice” (Schild 1989a, p. 160, my translation).

${ }^{12}$ Cf Patten 1999, p. 107: "Hegel's ... strategy .... is... to determine what a community must be like if it is to be successful in fulfilling its function of developing and sustaining free agency." Norrie 1991 remarks that "the strength and importance of Hegel's theory of punishment lies in a philosophical method which avoids the gap between reason and reality" (pp. 65-66) - although he later goes on to argue that Hegel achieves this only "by using reason to filter out all the recalcitrant elements" in reality, and that this amounts to "a kind of intellectual double-glazing" that overcomes "the gap between theory and practice...within philosophy, but only by transposing it outwith philosophy” (p. 80; emphasis original).

${ }^{13}$ Hegel 1821/1991. All subsequent citations to this work follow the translation in this edition. Citations are given without page references to the numbered paragraph which is cited. These paragraphs are usually followed by indented sections of Hegel's published text that, unlike the main paragraphs, were not read to students during the lectures. I cite these with the supplementary indication "Remark". Subsequent editors have then included further annotations which were drawn from the lecture notes of students. I cite these with the supplementary indication "Addition”. Unless otherwise indicated, the emphases in the quotations are Hegel's own.

${ }^{14}$ Brudner 2011, p. 499. What Brudner terms “the most comprehensive conception of freedom” is, in Hegel's terminology, the “idea” of freedom. Patten explains Hegel's usage as follows: “The 'idea' (Idee) of x, for Hegel, is defined as the 'concept' (Begriff) of x together with the 'actualization' (Verwirklichung) or 'objectivity' (Objektivität) of that concept.” (Patten 1999, p. $3 \mathrm{fn} \mathrm{6).}$

${ }^{15}$ See generally Mertens 2008. For a somewhat different but compatible exposition of Hegel's method in the Philosophy of Right, compare Patten 1999, p. 134-5.
} 
That Hegel's exposition moves from bare to rich understandings is important for our effort to extract - or, if necessary, to reconstruct - Hegel's theory of state punishment from his Philosophy of Right. What Hegel says about punishment in the section on Abstract Right cannot be taken as his theory of state punishment for the simple reason that the state is not even visible at this stage. The section on Abstract Right is pre-statal - not in an historical or an empirical sense, but in the sense that it sets out what can be explained about right and wrong before we even know of society and of the state. ${ }^{16}$ The explicatory movement from the bare conceptual notion of punishment to its institutional reality in the state is retraced in the next subsection.

\section{What Hegel says about punishment}

a) In Abstract Right, Hegel introduces the concept of punishment as the "cancellation of crime", which "is retribution in so far as the latter, by its concept, is an infringement of an infringement [of right]” (PR, § 101).

This infringement takes the form of an "injury" inflicted on the criminal (cf. $P R, \S 100$ ). This injury, Hegel maintains, is not only "just in itself” but also "a right for the criminal himself”:

"For it is implicit in his action, as that of a rational being, that it is universal in character, and that, by performing it, he has set up a law which he has recognized for himself in his action, und under which he may therefore be subsumed as under his right” ( $P R, \S 100)$; adding that: "In so far as the punishment which this entails is seen as embodying the criminal's own right, the criminal is honoured as a rational being." (PR, § 100 (Remark))

Not much is, and can be, said at this level of abstraction about what is actually to be done to an offender by way of punishment. Hegel merely clarifies that "in so far as crime ... has a determinate qualitative and quantitative magnitude, ... its negation ... also has a determinate magnitude" ( $P R, \S 101)$. All that this means is that punishment must in each case take some specific form. He also stresses that this "identity" of crime and retribution "is not an equality in the specific character of the infringement" but an equality of "value" (ibid.). This enables Hegel to cast aside the talionic notion of specific equality that embroils its proponents in absurdity (cf $P R, \S 101$ (Remark)). ${ }^{17}$ When equality is not taken as specific equality but as equality of value, it remains:

"merely the basic measure of the criminal's essential deserts, but not of the specific external shape which the retribution should take. It is only in terms of this specific shape that theft and robbery [on the one hand] and fines and imprisonment etc. [on the other] are completely unequal, whereas in terms of their value, ie their universal character as injuries, they are comparable.” (PR, § 101 (Remark))

\footnotetext{
${ }^{16}$ This is by now a widely accepted point among Hegel's interpreters. For those who make it explicitly, see eg Zabel 2011, p. 151; Brooks 2012, pp. 108-116, Norrie 1991, p. 76; Schild 2011, p. 106.

${ }^{17}$ Merle 2009 stresses that, for Hegel, "the absurdity lies not in an erroneous, literal determination, but rather in the axiom that 'what the criminal has done should also happen to him', and therefore in the specific equality or in talion law in contrast to the Hegelian principle of the negation of the negation” (p. 122). Hegel would therefore reject as misconceived Waldron 1992's attempt to salvage the talionic principle by having the sanction mirror the distinctive empirical quality of the wrongful act (its coerciveness, fraudulence, etc.).
} 
Moreover, we need to be mindful of the fact that, in Abstract Right, Hegel is not yet talking about "crime" and "punishment" in any familiar, recognisable sense. Hegel defines "crime" as a certain type of wrong:

"The initial use of coercion, as force employed by a free agent in such a way as to infringe the existence of freedom in its concrete sense - i.e. to infringe right as right is crime.” ( $P R, \S 95)$

This stipulation is incomprehensible unless one is also aware of what Hegel means by "the existence of freedom in its concrete sense”. For Hegel, in his first, highly abstract grasp of freedom, the "being" (or reality) of freedom is "the existence in which [the will] has embodied itself” (cf $P R, \S 92$ ). The thought is this: my freedom manifests itself ("exists") not in all the things I could possibly do, but only in the things I do do. ${ }^{18}$ By interacting with my environment, with things, my will - and thus my freedom - becomes embodied in that thing, ${ }^{19}$ and in its embodied shape it is vulnerable to coercion (cf $P R, \S 90$ ). When such coercion occurs not on account of an innocent mistake made by the other party as to whose thing it is, or on account of my having been tricked by the other party into believing that the thing is hers, then the other party's taking of my thing involves a negation of "also the universal ... element in the predicate 'mine' - i.e. my capacity for rights” ( $P R, \S 95)$. I am treated as if I was just an animal or an object; as if my will hadn't actually manifested itself in the thing. The other party's actions have placed me outside the practice of mutual recognition (of wills manifesting themselves in the world, ie, as "persons" in Hegel's sense). This matters because, as Hegel tried to show earlier, it is not through simple use of things, or through battle with and subjugation of other wills, that a human will achieves validation of its reality: it is only through recognition as a human will by other wills. ${ }^{20}$ This explains also why Hegel thinks it is self-contradictory for the perpetrator to interact with me as if I had no human will, no capacity for rights: his own capacity for rights hangs on interactions with beings which recognise his human will, including beings like me. ${ }^{21}$

This is how the matter stands conceptually, but it must also be made evident:

"When an infringement of right as right occurs, it does have a positive external existence, but this existence within itself is null and void. The manifestation of its nullity is that the nullification of the infringement likewise comes into existence; this is the actuality of right, as its necessity which mediates itself with itself through the cancellation of its infringement.” ( $P R, \S 97)$.

As Schild explains, these stipulations concern punishment but "only insofar as it is an act of legal coercion. These passages do not contain any theory of state-imposed penal sanctions". ${ }^{22}$

\footnotetext{
${ }^{18}$ See further Reyburn 1921, pp. 26-27.

${ }^{19}$ On Hegel's view of the reality of freedom consisting in the will giving itself an external existence, cf Reyburn 1921, p. 147.

${ }^{20}$ See Patten 1999, pp. 130-133, $144 \mathrm{ff}$.

${ }^{21}$ See also Stillman 1976, p. 171: "In a sense, [the offender's act] is an assertion, by a person living in a world of persons, that persons do not exist.”

${ }^{22}$ Schild 2011, p.106 (my translation). Anderson 1999 intriguingly compares the manifestation of the nullity of crime through punishment with the grading of a student paper: the grade manifests the paper's worth in the same way that punishment manifests the crime's nullity (pp. 378-380). She then rightly stresses that "annulment" signifies a conceptual relation between punishment and crime, not a material one. Hence, the notion of annulment does not turn Hegel into a closet utilitarian concerned with counteractions that "undo" the effects of crime (pp. 380-382). See also Norrie 1991, pp. 66-68 (arguing that interpretations that make Hegel out as a veiled utilitarian rest on unfamiliarity with Hegel’s philosophical method).
} 
Abstract Right, Jakobs reminds us, necessarily "leaves the question of the quantum of punishment without an answer" ("a theft could be negated by imposition of the death penalty, or a murder by a few months in prison") because it is "only the concept of right [that is visible here], not right as "a [protective] cloak for quantifiable interests where consequently also the response to a crime cannot yet be understood as a quantifiable setback to interests". ${ }^{23}$ But this is not merely a problem of the measure of punishment. It is also a problem of the form. Schild is correct to point out that all we can say about punishment in Abstract Right is that it is a second coercive act in response to the first coercion (negation of right) by the perpetrator, and that with respect to this quality of being a second coercion that responds to the first, it is rightful. We may even view this as establishing a bare communicative sequence of punishment being a response to the perpetrator's crime. But pain and harm (as setbacks to interests) only become conceptually possible when the "abstract/conceptual person" we encounter at the level of Abstract Right acquires the features of the real, bounded human being at the level of Morality: a being with goals, plans, interests, relationships, and a finite human life. ${ }^{24}$ One may therefore question whether even the term "injury" is appropriately employed at the level of Abstract Right to characterise the conceptual essence of punishment's determination. In Morality, the "quantitative and qualitative determinations" of crime become visible as the great variation in seriousness that arises because different crimes affect and violate different interests and needs, and it is here that crime is attributed to the perpetrator through the features of his culpable agency.

b) If we ask how punishment of crime can be effected in the social world, we find that this is impossible unless further elements are introduced. The response to crime that is possible in the sphere of Abstract Right is, merely, revenge - again, a concept that does not bear its ordinary meaning.

Revenge is "in its form, the action of a subjective will ... whose justice is altogether contingent", although its "content is just so far as it constitutes retribution" ( $P R, \S 102)$. "[A]s the positive action of a particular will”, however - as a reaction whose appropriateness cannot be validated - revenge "becomes a new infringement [of right]" (ibid.). ${ }^{25}$ Hegel's point is here that even when the victim's reaction is aimed at just retribution (as something distinct from mere revenge) - roughly speaking, at the infliction of proportionate suffering in response to the crime -, it cannot actualise just retribution. Being performed by the victim whose subjectivity is necessarily present (and expressed) in the penalising reactive act, the penal action cannot carry its justice on its face. It cannot be obviously and recognisably "just retribution" from the recipient's point of view. ${ }^{26}$

This is important, because it shows that it would be wrong to ascribe to Hegel the view that "what is revenge for the victim" becomes retributive punishment when performed by a more suitable (interpersonally validated) penal agent. Rather, his point is that in the absence of the possibility of interpersonal validation of the suitability of the victim's response, her reaction

\footnotetext{
${ }^{23}$ The quotations in the text are sentences and sentence fragments from Jakobs 2004, p. 27 (my translation), which are cited here in a different order from how they appear in Jakobs' original text.

${ }^{24}$ Patten 1999, p. 183: "A subject, in Hegel's technical sense ..., is an agent who conceives of himself not only as independent of his given situation but also as a bearer of certain ends and purposes that are distinctly his own."

${ }^{25}$ Cf also Johnson 2011, p. 161: "revenge attains justice, if at all, only by chance”.

${ }^{26}$ For further discussion of Hegel's concept of revenge and the movement from revenge to punishment, see Reyburn 1921, p. 152; Stillman 1976, p. 173 and Klesczewski 1991, pp. 232-239, 246-251.
} 
cannot be understood as annulling the crime but only as a fresh violation. ${ }^{27}$ Absent institutional structures in which the "universal" has taken on the task of responding to crime, "punishment” is objectively only coincidentally just, and remains subjectively unjust. ${ }^{28}$

c) The solution requires "a justice freed from subjective interest and subjective shape and from the contingency of power - that is, a punitive rather than an avenging justice" $(P R, \S$ 103). Hegel finds the conditions for the possibility of punitive justice in the developed institutions of civil society - to wit, in the courts. Punishment's institutionalisation in the courts overcomes two problems: (1) it completes the process that began with the "revenge taken by the heroes" of providing intersubjectively validated (formally just) punishment, ${ }^{29}$ and (2) it opens up the possibility of a procedure for the imposition of punishment in which D is suitably represented (Hegel's jury argument, discussed further in Section III.2 below).

Punishment, as administered by the courts, involves the application of proclaimed laws. These laws - and the judges who apply them - concretise the sanction that is equivalent in severity to the crime. Even in the sphere of civil society, philosophy cannot take us much further in the determination of actual punishments, which remains a matter shot through with contingency:

"It is impossible to determine by reason, or to decide by applying a determination derived from the concept, whether the just penalty for an offence is corporal punishment of forty lashes or thirty-nine, a fine of five dollars as distinct from four dollars and twenty-three [pennies] or less, or imprisonment for a year or for 364 days or less, or for a year and one, two, three days. ... It is reason itself which recognizes that contingency, contradiction and semblance have their (albeit limited) sphere and right... [H]ere, the only interest present is ... the interest that some kind of determination and decision should be reached ... within given limits.” $(P R, \S 214$ (Remark))

In this context, the danger to public order created by the crime matters; in a society that is sure of itself and generally law-abiding, the denial of right manifested in the crime will appear as an ineffectual individual aberration, and will need a less severe response ( $P R$, §218). Accordingly, sanction-severity will and ought to decrease. As Brooks explains: "We punish crimes to the degree we as societal members believe they pose genuine threats to our just institutions". ${ }^{30}$

Hegel also returns to the objective and subjective justification of punishment. Picking up on his contention that the form right takes in civil society - as posited law - and the institutionalisation of the judicial function in the courts together overcome the contradictions in which the response to crime is mired outside these frameworks, Hegel stresses that now that the injured universal has:

\footnotetext{
${ }^{27}$ See further Stillman 1976, p, 173. It is worth drawing attention to the advancement that Hegel's argument contains over Locke's exposition of the "natural executive right to punish", whose exercise in a pre-institutional state of nature is in some respects comparable to the pre-institutionalised response to crime that Hegel refers to as “revenge”. If Hegel's analysis of revenge is correct, it suggests that the exercise of a Lockean right to punish necessarily involves pre-institutional agents in punishment's first contradiction (that, if we punish in exercise of this right, the form of the punishment will constitute a fresh violation of the punished person's right). Hegel thereby demonstrates (contra Locke) that the institutionalisation of punishment is not merely an instrumental but a moral necessity.

${ }^{28}$ See also Klesczewski 1991, pp. 249-250.

${ }^{29}$ On the process of the "formalisation of revenge" which falls into the emergence of states/public authority, see Klesczewski 1991, pp. 255-259, Du Bois-Pedain 2011, pp. 217-218, and Reyburn 1921, pp. 152-3.

${ }^{30}$ Brooks 2012, p.116.
} 
“tak[en] over the prosecution and penalization of crime, ... these [responses] ... are transformed into the genuine reconciliation of right with itself, i.e. into punishment. Objectively, this reconciliation applies to the law, which restores and thereby actualises itself as valid through the cancellation of the crime; and subjectively, it applies to the criminal in that his law, which is known by him and is valid for him and for his protection, is enforced upon him in such a way that he himself finds in it the satisfaction of justice and merely the enactment of what is proper to him.” $(P R, \S 220)$

This means it is at least problematic to suggest - as Johnson appears to do - that in Hegel's justification of state punishment, the perspectives of victim, society, and offender remain somehow distinct. ${ }^{31}$ The justification of punishment in the sphere of civil society necessarily includes the justification of punishment in respect of victims and offenders, since their perspectives are distinct from but subsumed within the "perspective" of society. Hegel makes this point even more bluntly in his Lectures on Natural Right and Political Science (LNR) ${ }^{32}$, where he explains that, in the sphere of civil society:

"The exercise of right by the universal is no longer directed at criminals as something contingent and an external power. Right also belongs to criminals: it protects them and is accomplished in them as their power and essence.” ( $L N R, \S 112)$

The notes taken by his student Wannenmann during Hegel's lecture add that:

"Now the right is the ground, it is not the injured party who has to be given satisfaction but the law. ... In the state this subjective side [of the injured party] falls away, and it is not so much that retribution is exacted from the wrongdoer as that he is requited for this action.” (LNR, §111 (Notes))

d) The evolution of civil society necessitates full statehood. In an established state, the administration of justice is one of the state's functions. Hence, at this point, punishment of crime is necessarily state punishment. ${ }^{33}$

The sophistication of Hegel's argument can be appreciated best when one compares it to views that tie both the origins and the legitimacy of the state much more directly to the state's role in punishment. Consider, for instance, McDermott's account which he develops out of A. John Simmonds' contemporary restatement of a Lockean approach. McDermott contends that the Lockean "natural executive right to punish wrongdoing" is in fact a duty to punish wrongdoers, coupled with a power to do so, but that the difficulties involved in fulfilling this duty through disorganised individual action is what obligates people to create a central institutional structure to co-ordinate and centralise their punishment efforts. Thus punishing wrongdoers becomes the first and foremost state function (including a secondary right to raise taxes to finance this task) - legitimated by necessity and hence even in the absence of the consent of each citizen. ${ }^{34}$ Hegel's account makes it clear that the functions of the state are much broader than merely the administration of justice. The state's powers are necessitated by the fact that civil society - the "system of wants" which organises itself through the actions of self-interested subjects according to the logic of the market - remains unstable unless some institutional structure emerges which places the self-interested market participants in a setting

\footnotetext{
${ }^{31}$ Cf Johnson 2011, pp. 158-159.

${ }^{32}$ Hegel 1817-18/2012.

33 This is argued at greater length in Du Bois-Pedain 2011, pp. 219-221.

${ }^{34}$ McDermott 1999.
} 
where their self-interested pursuit of options ipso facto advances the common weal. The state does not exist merely (not even primarily) to punish: judicial mechanisms of conflict resolution will, as Hegel contends, evolve before full statehood does, and they are important but not of themselves sufficient to guarantee an order of freedom. ${ }^{35}$ The protections of a criminal justice system or crime control are not the most important driver behind the formation of a state. Instead, the necessity of the state is not as such linked to criminal punishment.

e) The connecting principle between the different frameworks is that of recognition. As Alan Patten explains,

"The theory of recognition provides the bridge between the concern for the development of individual freedom and the focus on the social institutions and practices that make up a community of free individuals.”36

But while the conception of human beings as moral agents engaged in a practice of mutual recognition is central to Hegel's account of what freedom is, and of how the social structures of a well-ordered state evolve with necessity from this basic character of human relations to the physical world, and to each other, Hegel does not justify or explain the act of imposing a sanction on the offender as a moral communication. Punishment ultimately becomes a public task because of the inevitable contradiction to which "punishment" by the victim leads. Public authority, and institutionalised law enforcement, develops out of this necessity to assign the task of enforcing the sanction to an authoritative entity in which the offender can also recognise himself.

Once the sanctioning of violations of right has become a collective, public task, considerations of the proper aims and performance of public tasks more generally enter the picture. Thus, Hegel says that dangerousness now becomes a relevant criterion in deciding which shape sanctions should take, and what level of severity is generally appropriate to deter crime. The non-talionic content of the notion of "equivalence in value", together with the dialectic movement from the stage of Abstract Right via Morality to Ethical Life in the state, makes the incorporation of such aspects into penal practice possible, because no precise sanction is prescribed at the levels of Abstract Right, Morality, or indeed Ethical Life.

Punishment and crime are thus, as Brooks and others have rightly pointed out, far more complex notions by this stage than when the bare-boned concept of retributive punishment (as an infringement-cancelling infringement of (crime's) first infringement of right as right) is introduced in Abstract Right. In Morality, crime acquires the "quantitative and qualitative determinations" of real injuries to specific interests. In the sphere of civil society, crime as a "danger to society" (to possibly different degrees at different times and in different contexts) becomes additionally visible, and here notions such as deterrence or the corrective functions of punishment could find their proper sphere of application in the determination of sanctions in individual cases (cf PR, $\S 99$ (Remark)). The resulting theory is - with Schild and Brooks best classified as a unified theory which "aspires to offer a single, coherent theory of punishment that brings together retributivist, deterrent and rehabilitative elements without substantial conflict”. ${ }^{37}$

\footnotetext{
${ }^{35}$ See Hegel's discussion of the "Notstaat", something like the minimal state, that we find at the stage of civil society.

${ }^{36}$ Patten 1999, p. 123.

${ }^{37}$ Brooks 2012, p.104. See also Schild 2004 ("integrated unified theory”). See also Merle 2003 (arguing that in Hegel's theory, punishment aims at "the restoration of a legal community that includes the criminal too" and
} 
Brooks claims for the resulting theory that it not only sets "clear limits on who can be punished" but also "clear limits on acceptable punishments". ${ }^{38}$ Especially the second claim is in need of further investigation, however. On the face of it, Hegel has little to say about "the specific external shape” ( $P R, \S 101$ (Remark)) that punishments take, except that these shapes differ in different societies. For Hegel, levels of punitiveness and sanction types are products of their time: "proportionate to the conditions of their time; a criminal code cannot be valid for every age, and crimes ... can be met with lesser or greater degrees of repudiation" ( $P R$, $\S 218$ (Addition)). It appears to remain very much an open question which punishments are legitimate ones to impose on the offender.

\section{The first problem: Justifying punishment vis-à-vis the offender}

To justify punishment vis-à-vis the offender himself means to demonstrate that his punishment is compatible with his freedom - that it affirms rather than violates it. ${ }^{39}$

Evidently, the claim that the offender "wills" or "consents to" his own punishment is not to be taken empirically: real-life offenders often resist punishment and deny that its imposition on them is justified. The argument rather amounts to a claim that real-life offenders, if they are intellectually honest and morally committed human beings, would have to acknowledge that the punishment they receive is warranted and appropriate as a response to their own prior actions, and that they themselves have a stake in being punished in this way. This is what Brudner means when he argues that:

"what distinguishes penal force by state officials ... from ... wrongful force ... is [that the former] could be accepted by the sufferer, considered as a free and independent person, as being consistent with his or her freedom ... [and] as self-imposed ... by virtue of his choice to do what he did." 40

That Hegel sees the need to provide such a justification stands in positive contrast with various other approaches which, generally speaking, do not (whether these are variants of forfeiture or deterrent theories). ${ }^{41}$ His first explicit justification of punishment vis-à-vis the offender is the suggestion we find in $P R, \S 100$, that punishment is "a right for the criminal himself": "For it is implicit in his action, as that of a rational being, that it is universal in character, and that, by performing it, he has set up a law which he has recognized for himself in his action, und under which he may therefore be subsumed as under his right". This can be read as a demonstration that the offender "wills" his own punishment. But how successful an argument is this?

Throughout this discussion, a peculiarity of Hegelian terminology must be borne in mind. A "person" in Hegel's sense is, most emphatically, not yet (contrary to what Knowles has

\footnotetext{
“[g]eneral prevention, retributivism, betterment, etc. are subordinated to this ... aim and are, insofar, integrated in Hegel's theory in a secondary role” (p. 176).

${ }^{38}$ Brooks 2012, p. 114.

${ }^{39}$ Brudner 2009, p. 2.

${ }^{40}$ Brudner 2009, p. 2.

${ }^{41}$ Cf Brudner 2009, p. 45: "[T] the thinking Agent, punishment conceived as by nature an external threat is an affront to dignity, for, like any threat to freedom, it treats agents as manipulable objects rather than as ends. Though the thinking Agent will concede that ... disincentives to wrongdoing are needed for some or even most, it will not allow that punishment be conceived essentially in this way; for if it is, then punishment is incompatible with its freedom” (emphasis original).
} 
claimed) "the familiar protagonist of modern liberalism, the agent conscious of himself merely as distinct from other individuals". ${ }^{42}$ Hegel's "person" is an abstraction of a far more extreme kind: it does not contain anything which depends on the "particularity of the will", as Hegel puts it, such as "desire, need, drives, contingent preference, etc.” ( $P R$, $\S 36)$. Hegel's "person" is thus not yet an individual (and hence, his use of the term is ripe for misunderstandings). His conception of "personality" (as marking a capacity for the attribution of rights) conceives of the human agent merely as an entity aware of its distinctness from its environment, its self-identity, and its ability to effect changes in the external world through interacting with it. ${ }^{43}$ To meet the "familiar protagonist of liberalism", the "individual", we have to wait until we enter the sphere of Morality, where the "person" acquires subjectivity a conscience, plans, talents, projects, in other words: a life - and thus becomes a selfdetermining "subject". Subjectivity/morality is where human beings become visible as selfdetermining, feeling and vulnerable agents: "morality ... represents ... the real aspect of the concept of freedom” ( $P R, \S 106$ (Remark)). And, as Hegel well knows, the self-determining subject cannot function in isolation. It is only when the self-determining subject is placed into a web of relations with other self-determining subjects - when he finds his place and station in, and is perceived to be a "member" of, civil society - that freedom becomes liveable without self-contradiction.

\section{Setting out the problem}

It is clear from its location in the sphere of Abstract Right, that the argument that the offender wills his own punishment cannot carry the full weight of justifying punishment vis-à-vis the offender. All we can possibly find in this sphere is an explication of the formal connection that holds between (criminal) wrongs and punishments. On this formal level, wrong is connected to right as right's negation, and punishment is connected to wrong as wrong's negation, hence punishment is connected to right as the negation of the (first) negation. On this formal level, the offender's will is connected to right as a system in which he partakes through any manifestation of his will in the world. Therefore, on this formal level, the offender's will is connected to wrong - the denial of right - in the shape of a selfcontradiction. And this, again through a purely formal logic, connects the offender's will [his rational being] to punishment - the restoration of right - as necessarily self-willed. It is an argument that we can indeed make vis-à-vis any rights-violator. But if this were to remain all that we say to an offender to justify his real-life punishment, it would amount to a refusal to justify his punishment to him. To see this, we have to understand the limitation of the argument made in Abstract Right.

Abstract Right can conceive of only one dimension of real-life penal sanctions. This is the penal sanction's rational intelligibility to a being who partakes in the practice of manifesting his will in the world. Such a being understands that punishment constitutes the (second) negation of his (first) negation of right. He also understands that this second coercion is rationally endorsed by any agential operator in the system of right, himself included.

But, of course, there are other dimensions of real-life penal sanctions that Abstract Right cannot see. There is the aspect of the real-life penal sanction being a communication with the offender's moral self and self-understanding. In that dimension, the real-life penal sanction is

\footnotetext{
${ }^{42}$ Knowles 2001, p. 126.

${ }^{43}$ As Reyburn 1921 explains in the context of his discussion of property, personality is a deliberately reductive concept: "Personality as such does not exist in its ... nakedness. What exists as a person is always more than a person, and is constituted both by particular ends and by more concrete universals which are not explicit in personality itself.” (pp. 128-9).
} 
something that can be variously experienced by the punished individual as an outrageous imposition, an insult, or contrariwise as a censuring of his earlier conduct that he inwardly accepts. In this dimension, punishment is something that speaks to, and resides within, the offender's own conscience. An offender with a properly developed human conscience will, in this dimension, endorse an "objectively just" real-life penal sanction as just (below I'll have more to say about what an "objectively just" penal sanction is). By the same token, he will resent an objectively unjust real-life penal sanction as an outrage/insult to his personality. ${ }^{44}$ An offender with an insufficiently or improperly developed conscience might, of course, rail inwardly against even an objectively just real-life penal sanction. For such an offender, undergoing the real-life sanctioning process will, ideally, lead to a maturation and reform of his faulty conscience.

It is worth observing that Hegel provides us with the resources to addresses this dimension of punishment in his move from Abstract Right to Morality. Hegel's discussion of the human conscience, moreover, also puts the finger on the very problem that was left to a later solution in the preceding paragraph: the question how one identifies an objectively just penal sanction. Here is the problem: absent any dimension external to conscience, the claim by conscience to be the sole arbiter of right and wrong will prevent the above mechanism from working. ${ }^{45}$ The subject must draw on sources of moral knowledge beyond its inner conviction before it can make sense of any externally imposed real-life penal sanction as "objectively just". ${ }^{46}$ This is why, with Hegel, we can see how, in order to account for, and legitimate, punishment, we must move beyond the sphere of Morality to that of Ethical Life. What partaking in Ethical Life makes possible is the intersubjective validation of real-life penal sanctions, and thus the recognition of some of these sanctions as "objectively just". This, in turn, is needed both for punishment to be an appropriate engagement of, and with, the offender's own conscience, and for punishment to be what is rationally willed by participants in the system of right.

\section{Self-willed punishment through self-willed law?}

The major development through which intersubjective validation has become possible at the level of Ethical Life/Civil Society, is, of course, the positing of right as law ( $P R, \S 211)$, in conjunction with its application through courts $(P R, \S 221)$. This can give rise to an argument that, as a participant in, and beneficiary of, the order of freedom that has been made possible when right has become posited as law and enforceable in the courts, the offender should be reconciled with the application of that law to him. His rational will must endorse his own punishment. This indeed appears to be Hegel's argument when he points out that the injured universal which "has its distinctive actuality in a court of law ... applies to the criminal in that his law, which is known by him and is valid for him and for his protection, is enforced upon him in such a way that he himself finds in it the satisfaction of justice and merely the enactment of what is proper to him." ( $P R, \S 220)$. Becchi consequently suggests that it is the fact that the offender's punishment is provided for by law that supplies the justification for its imposition on him. ${ }^{47}$

\footnotetext{
${ }^{44}$ Mohr 1997, p. 119, quotes Hegel as observing, in his 1819/20 lectures, that "savage punishments only embitter the soul and, instead of discouraging crime, serve as an invitation to its commission.”

${ }^{45}$ On conscience’s “inadequate judgmental structure”, see Moyar 2011, p. 137. See also Dudley 2002, p. 53 (noting that "the logical limitations of judgment ... limit the moral will", thereby preventing it from "being the actuality of freedom”.)

${ }^{46}$ Compare Zabel 2011, pp. 135-136.

${ }^{47}$ Becchi 2011.
} 
As it stands, the argument cannot be deflected. But we must acknowledge how limited it really is. Recall - with Brooks - that at this stage in the development of Hegel's theory, "crime becomes a violation of positive law, rather than of abstract right," and while Hegel "does not abandon the earlier view that the values of crime and its punishment are linked", it is (at this mature stage of exposition) "civil society - rather than only the criminal himself in acting - [which] has a say in which punishment is most appropriate". ${ }^{48}$ This is extremely important. It means that it is only in the thinnest possible sense that it now matters that the offender "wills his own punishment”. He doesn't will any reaction to his crime that takes any particular form, indeed the very notion that he wills a response "equivalent in value" to his criminal act now means that he wills that society's positive law be enforced against him. There is no "equivalence in value" independent of the scheme of penal sanctions provided for in the positive law. So all we are doing here is pointing to the "law-ness" of the law, and lawness's connection to right, which does not get us very far in justifying to an offender the specific penal sanction that the law imposes on him. We would at least need to supplement the argument with a further demonstration of how the (philosophically underdetermined) choices of the form and severity of punishment that we have made through our legal institutions are properly thought of as the offender's choices, too. Perhaps the way to go is to argue for some broader representation the offender has in the political system in which these choices have been made? ${ }^{49}$ We could, for instance, develop the idea of self-representation or selfimposition in respect of the legislative process, arguing that the offender has willed the punishment that the law provides for his case through his participation and representation in the creation of democratic laws. But how would such an argument then remain distinct from social contract arguments? ${ }^{50}$

We need not pursue this question any further here because this is not the representational argument Hegel makes. He relies on a different idea: that the criminal finds himself represented in the jury, and that it is this which reconciles the criminal to the determination made by the court. Hegel sees that any decision by a court of law involves an ineradicable aspect of "subjective conviction and conscience" $(P R, \S 227)$ on the part of the decision-maker in arriving at his determinations of fact and law; and notes that these determinations may well collide with an outright denial on the part of accused. As one of his students, Hotho, noted during his lectures, if in the face of such a denial:

"the subjective conviction of the judge [were] to prevail, an element of harshness is again introduced, for the person in question is no longer treated as a free individual. The mediation ... is the requirement that the verdict of guilt or innocence should emanate from the soul of the criminal - as in trial by jury.” $(P R, \S 227$, Addition $(\mathrm{H}))$

It is because the offender is judged by "his peers" and not by a professional caste apart from him, that the jury's judgment embodies his own judgment. The criminal defendant's peers are like him in their particularities - they are of comparable social status, and the like - and this is what, to the extent that arriving at a judgment involves the subjectivity of the decision-maker, enables the defendant to place "confidence ... in the subjectivity of those who arrive at the verdict” ( $P R, \S 228)$. In fact, for Hegel this point is so important that he even says that it is no counter-argument to say that a professional judge might do a better job at judging a case accurately ( $P R, \S 228$ (Remark)).

\footnotetext{
${ }^{48}$ Brooks 2012, p. 115.

49 Schild explores this possibility when he investigates the basis for the "trust" which, according to Hegel, individuals must be able to place in the state and its institutions. See Schild 1989a, pp. 165-167.

${ }^{50}$ It is therefore perhaps unsurprising that Knowles 2001 concludes that Hegel's theory requires a contractarian supplement or "fix".
} 
Is this just jury romanticism, or will this argument see us through? Even if we were to grant that jury members can be seen as persons of similar life experiences, views, motivations and dispositions, to the defendant, such that there is a sense in which his subjectivity is "represented" by them, ${ }^{51}$ this may not ultimately be an argument that can carry much weight. Note that the jury argument is introduced by Hegel not so much to bolster the law argument previously discussed but to address a further requirement for a procedure of arriving at a judgment against the defendant which he can also be shown to have accepted (cf. $P R, \S 221$ ). This procedure carries with it the need for applications and determinations that involve the subjectivity (the reasoning abilities, conscience and conviction) of the decision-maker. It is precisely as a solution to this problem that Hegel's argument fails to convince. The jury system, with its concomitant absence of a duty to give reasons which undermines effective appeal court control of the logical defensibility of conclusions reached, exposes a defendant to a high risk of being tied, not to his ethical will as manifested in the jury's decision, but to the irrational, arbitrary side of his being (because irrationality and arbitrariness of judgment are what might arguably be imposed on him by the jury ${ }^{52}$ ). If this happens - and nothing in the procedure can effectively prevent it from occurring - it is not his rational, ethical will that the judgment imposes on him. Given this systemic, ineradicable risk, the defendant's selfrepresentation in the jury carries too little weight to provide a full justification of the punishment inflicted on him.

The upshot from our discussion so far is that the law argument and the jury argument do not take us far enough in showing that an offender's actual punishment is an acknowledgement and expression of his freedom. But there is another argument on which we can draw: an argument that focuses on what punishing an offender says about his status in our social world. This is the notion that punishment is a mark of recognition, that it validates the offender's status as a self-determining human agent participating in our practices of mutual recognition. As Jane Johnson puts this point: "[In] spite of embodying a rejection of his act, the criminal's punishment still acknowledges his status as a rational and autonomous individual”. ${ }^{33}$ Hegel himself chooses an even starker formulation:

"In so far as the punishment which [treating the criminal as having set up a law which he has recognized for himself in his action] entails is seen as embodying the criminal's own right, the criminal is honoured as a rational being.” ( $P R, \S 100$ (Remark))

It is this notion, that punishment honours the offender, whose implications for the subjective justification of his punishment I now want to explore a little further.

\section{Punishment as a token of recognition? The honour argument}

What does it mean to say that punishment honours the offender? Kurt Seelmann summarises the point as it has been developed by Hegel (who in turn draws on a line of reasoning instantiated by $\mathrm{Kant}^{54}$ ) as follows:

\footnotetext{
${ }^{51}$ Empirically, one might question the assumption that a defendant recognises himself in the jury. Jacobson, Hunter and Kirby 2015, who conducted an extensive interview study in English Crown Courts, note "a considerable degree of mistrust towards juries by defendants” (p. 179).

${ }^{52}$ In recent years, jurors' conduct has increasingly given rise to "contempt of court” proceedings against jurors (for discussion and examples, see Smith 2015). Such cases only scratch the surface of juror prejudice, irrationality and intellectual limitations affecting the quality of jury deliberations and decisions. - I thank Mark Reiff for asking me to clarify this point.

53 Johnson 2011, p. 160.

${ }^{54}$ Seelmann 2014, pp. 113-114 carefully retraces that line.
} 
"The honouring of the offender as a reasonable creature thus consists in the fact that one universalises his action under the principle that the perpetrator, qua rational human being, must also have endorsed his punishment in his own will, and therefore cannot now complain when he is treated according to the norm he set up through his acts. It is only by punishing a human being that one really treats him as a responsible agent, as a moral person-in contradistinction to an animal." 55

Seelmann is certainly right to emphasise that "it is hardly far-fetched to maintain, as Hegel does, that punishment must be justified to the perpetrator and that it therefore matters what commitments are implied by his criminal act." ${ }^{56}$ Stated in those terms, however, the honour argument does not appear to add much strength or substance to the law argument we have already explored above. What is then decisive for both the objective and the subjective justification of punishment is that the criminal's act contains an implicit negation of the fundamental structure of a system of mutual recognition of free agents - that we relate to each other as bearers of rights - and that, since he cannot but partake in this system, which is a precondition for and creation of his freedom as much as anybody else's, he is committed to negating those actions on his part that appear to undermine or deny this lived reality of freedom.

Yet when we look further into the intellectual roots of the notion of recognition, we can see that the honour argument may also be highlighting something else. What we find here is, as Seelmann says, "an ultimately positive orientation of the penalising agent towards the offender". ${ }^{57}$ Seelmann explains that the idea that the punished individual is honoured by the imposition of punishment is connected to a view of the self and personhood that emerged during the early Enlightenment and ties personhood to "the imputation of responsibility for one's agency". ${ }^{58}$ It was then seen as fundamental that:

“Only someone who has a certain mental relationship to his self, someone capable of scrutinising himself in reflective thought, can be a responsible agent—and it is only to a being with these qualities that one can impute actions and omissions as their own. In classical modern philosophy, this capacity to develop a mental connection to oneself and thus to reflect critically on and direct one's conduct determines personhood; which is, to that extent, a mark of honour. Conversely, someone is recognised as a personhas this honour bestowed upon him—as soon as an act is imputed to him."59

In Locke's work, “imputation of an action to a human being as responsible for the action signals recognition of the personal identity of this human being, encompassing both his consciousness and emotions." ${ }^{0}$ Through drawing this connection, the "attribution of responsibility [through punishment can be thought of as] constitutive of the person." 61

This also provides a point of connection between Hegel's honour argument and modern censure-based justifications of punishment which are rooted in the same Lockean conception of the person. Punishment can then be said to honour the offender because and to the extent

\footnotetext{
${ }^{55}$ Seelmann 2014, p. 115.

${ }^{56}$ Seelmann, 2014, p. 115.

${ }^{57}$ Seelmann 2014, p. 115.

${ }^{58}$ Seelmann 2014, p. 117.

${ }^{59}$ Seelmann 2014, p. 117.

${ }^{60}$ Seelmann 2014, p. 118.

${ }^{61}$ Seelmann 2014, p. 118.
} 
that it communicates with him, thereby implicitly recognising the offender's status as a rational human being. ${ }^{62}$

If this interpretation of the honour argument is accepted, it provides us with an answer to Ristroph's first challenge. Hegel's theory does, contra Ristroph, address its justification of punishment to "real people". It conceives of the addressee of the penal law as an individual, a person in Locke's sense - someone whose ability to lead a self-directed life is acknowledged and recognised through the attribution of responsibility that punishment instantiates.

But this answer also takes us straight to Ristroph's second challenge, in that it leads us to question how a censuring recognition of offenders' humanity is compatible with what we do to offenders by way of "real punishment": punishments that, as Ristroph is right to remind us, (frequently) involve "the flesh and blood of hopelessly embodied beings" 63 and the use of physical force against "vulnerable bodies". ${ }^{64}$ In part, this is a question about particular forms of punishment, which may silence the offender and/or exclude him permanently from the moral community. More fundamentally, this is a question about the relationship, in a Hegelian framework, between suffering-inducing sanctioning practices and the honour that the punishment bestows.

\section{The second problem: Punishment as "hard treatment" in the realm of finite things}

It could be argued that a Hegelian might hold a positive view of penal suffering. Suffering, in this line of thinking, may not be a challenge to honour if one's honour lies (also) in undergoing the suffering that deserved punishment brings. ${ }^{65}$ Here, the idea is that the selfrespecting person, in being committed to accepting her punishment as an upshot of the practice of mutual recognition in which she also has a stake, must ipso facto be committed to undergoing the suffering that her (appropriate) punishment entails. From a Hegelian perspective, one could also question whether the very notion of an offender rationally willing his own punishment is not rendered incoherent if the offender is taken, by this, to will only a reaction to his crime that he does not experience as a hardship. ${ }^{66}$ That what is undergone by way of punishment is a form of hard treatment can then be read as signalling acceptance of one's punishment, and can for this reason be seen to reinforce honour. ${ }^{67}$

It is, thus, far from clear that a Hegelian theory has to accept Ristroph's second challenge, her insistence on a distinctive justification for punishment's "physically restrictive and injurious forms". ${ }^{68}$ In the discussion that follows, I connect the "hard treatment" aspect of punishment to Hegel's definition of punishment as an infringement of an infringement of right, and show that Hegel's theory requires punishment to be a hardship. Next, I address the question what sort of hardship punishment may be. At this juncture, the emphasis moves from hard

\footnotetext{
${ }^{62}$ See Seelmann 2014 for an exploration of this similarity between Hegelian-Idealist and modern censure-based justifications of punishment, such as the theory developed in von Hirsch 1993.

${ }^{63}$ Ristroph 2011, p. 470.

${ }^{64}$ Ristroph 2011, p. 471.

${ }^{65}$ Peter Ramsay raised this point in discussion with me.

${ }^{66}$ This is suggested by handwritten notes Hegel made on his lecture manuscript, where he insists that there is no punishment in the case of the "Roman who wanders about, smacking other citizens, with his slave following him with a sack of money from which the criminal fine is paid immediately", or in the case of the person who commits murder because he wishes to be hanged for it (to punish him, Hegel suggests, we need to convert his punishment into imprisonment). See Hegel 1821/2000, p. 189.

${ }^{67}$ I owe this point to Miriam Gur-Arye.

${ }^{68}$ Ristroph 2011, p. 472.
} 
treatment - the general form of the penal response - to the infliction of suffering as a nonincidental though variable aspect of particular kinds of punishments. Here, how punishment affects the individual becomes more prominent. After exploring what can be drawn from Hegel's theory about permissible and impermissible forms of punishment, I argue that, so long as the suffering that is incidental to the infliction of permissible penal sanctions does not exceed a certain level, the punished individual can still undergo his punishment with his sense of self intact. While this suffices to answer Ristroph's challenge, it does not yet allow us to resolve the tension between the infliction of suffering and punishment's alleged "ultimately positive orientation of the penalising agent towards the offender". ${ }^{69}$ How and why this orientation might be at risk in penal action is explained in the last sub-section by considering what responding to crime has in common with responding to transgressions by the will more generally.

At the outset, we should note that while "hard treatment", "harm" or "penal suffering" are all commonly in use to refer to the phenomenological or factual aspect of punishment, they are not necessarily co-extensive, and also put the emphasis on different aspects of punishment's "real form". Harm, in its most general sense, consists in a setback to a recognised interest, and/or in the destruction or removal of access to a resource. It can also be used to mean physical injury. Hard treatment is a wider notion in that it can consist in any libertyrestraining or otherwise burdensome imposition on a person. What makes such treatment recognisable as penal hard treatment is that it is imposed as a way of communicating penal censure. Penal suffering designates the experience of undergoing court-imposed punishment. Sometimes the usage is conceptual, in that any punishment is taken to impose penal suffering; sometimes the expression is reserved only for punishments that are accompanied by high levels of physical or psychological pain. I mean by penal suffering the experience of undergoing the kinds of punishment that, due to their duration and form, are "physically restrictive and injurious” in Ristroph’s sense.

\section{Why the hard treatment element needs additional justification}

For Hegel, the hardship of punishment is bound up with the "infringement of an infringement [of right]" that punishment amounts to, since penal hardship is the (conventionally defined) form that this infringement takes: an "injury", equivalent "in value" to the severity of the offence (cf. $P R, \S 101$ ). To avoid a potential source of confusion, it should be clarified that when Hegel speaks of "injuries" in this context, he does not refer to physical injuries or restraints but to curtailments of the offender's will. The offender needs to be brought up short. ${ }^{70}$ Could this (in Hegel's view) be done through an act that does not take the shape of hard treatment? This is difficult to imagine. The act must be recognisable as punishment. In Hegel's discussion of the significance of crime in the sphere of civil society ( $P R, \S 218)$, it is nowhere suggested that punishment could disappear completely, only that it may become milder and milder as the meaning of crime for society changes. ${ }^{71}$ But to make punishment disappear is for the sovereign power only, through pardon, and it is only on the cards

\footnotetext{
${ }^{69}$ Seelmann 2014, p. 115.

${ }^{70}$ See Schild 2011, p. 103. See also Brudner 2009; Merle 2009, p.133.

${ }^{71}$ Schild 2011, p. 106. Jakobs 2004, p. 26, suggests that the infliction of the pain of punishment, for Hegel, has not primarily a deterrent dimension (as for other theorists) but a symbolic dimension: it makes the incompatibility of what $\mathrm{D}$ has done with an order of freedom manifest. As such, he argues that some degree of hardship is, from a Hegelian perspective, indispensable: "The pain of punishment serves to reinforce the validity of the norm at the cognitive level; this is the purpose of punishment whereas the negation of the negation of [the norm's] validity by the criminal is [punishment’s] concept.” (Jakobs 2004, p. 29 (my translation)).
} 
exceptionally, an option in specific cases and in response to their specificity, not as a general response to crime. ${ }^{72}$

Some of Hegel's commentators simply deny that the fact that punishment takes the form of a hardship on the offender means that a Hegelian also has to justify punishment as a hardship. Johnson argues that it is precisely because punishment is, for Hegel, the manifestation of right, that he would reject any account of punishment that also endowed it with the feature of being "a harm" done to the offender:

"However, punishment for Hegel is not an independent harm or evil act, but rather it is an integral part of a process initiated by a criminal action, which cannot meaningfully be abstracted from this context. It is not the harm of punishment that should be in the foreground in justification, since harm is just a side effect or consequence of having to punish."73

The reason why this deflection strategy is problematic is that, conceptually speaking, an element of "hard treatment" may be indispensable for the very intelligibility of an act as "punishment". ${ }^{74}$ If a Hegelian accepts that punishment can only manifest itself in the world through an act that bears the hallmarks of hard treatment, then she cannot split the harm in punishment off as being "just a side effect or consequence of having to punish". It is, then, part of what punishment is. It is part of its rationally necessary being, part of what Hegel calls "truth" or "reality".

There are, indeed, indications in Hegel's work that he saw the hard treatment element of punishment in those terms. In $P R, \S 99$, Hegel insists that we must not fall into the trap of regarding "crime and its cancellation, which is further determined as punishment, ... only as evils", since such a "superficial" point of view sets the "objective consideration of justice, which is the primary and substantial point of view in relation to crime", aside. However, he then moves on to consider the secondary point of view on punishment - "punishment as a phenomenon". In this perspective, punishment does become visible as something done to an impressable individual that is experienced by this individual as an imposition, a setback, an evil or harm. It matters here that punishment makes itself felt. In short, Hegel does accept and thinks it necessary - that punishment as something done to a criminal must be in some way painful and/or harmful, sufficiently so to impress itself upon the criminal as the experience of being punished.

How may, and should, punishment make itself felt? Initially, it appears that Hegel is ready to place this question beyond the concerns of philosophy. In explaining what he means by the postulation that "in so far as crime, by its existence, has a determinate and qualitative magnitude, ... its negation, as existent, also has a determinate magnitude", namely "an equality ... in terms of its value” $(P R, \S 101)$, Hegel is careful to stress that:

"The qualitative and quantitative character of crime and its cancellation thus falls into the sphere of externality, in which no absolute determination is in any case possible. In the realm of finite things, the absolute determination remains only a requirement, on which the understanding must impose increasing restrictions ... If we ... overlook this nature of the finite realm [and] proceed no further than abstract and specific equality,

\footnotetext{
${ }^{72}$ This point is made by Neumann 2011, p. 164.

73 Johnson 2011, p. 160.

${ }^{74}$ For many philosophers outside the Hegelian framework, harm is an essential element of the notion of punishment. See, eg, Boonin 2008, p. 6; Feinberg 1970, p. 67.
} 
an insuperable difficulty arises when we come to determine punishments ... Value [is] the inner equality of things which, in their existence, are specifically quite different ... In the case of crime, ... equality remains merely the basic measure of the criminal's essential deserts, but not of the specific external shape which the retribution should take.” (PR, § 101 (Remark))

Now, if we accept - as Hegel does, and as we must also - that anyone who is actually punished by our institutions of criminal justice, is punished in the "realm of finite things", and if we accept - as Hegel does - that in this realm, our understanding must impose increasing restrictions of the requirement of the determination of punishment in terms of an equality of value, and that in this realm we can in any case only ever achieve an "approximate fulfilment" of this requirement, then we have - as I see it - also accepted that the justification of real-life penal sanctions requires a justification in their very dimension as "approximations", which includes also an account of the restrictions our understanding has found it necessary to impose.

Thus, even on Hegel's view, a full justification of real-life penal sanctions vis-à-vis the punished individual must include a justification of the actual shape that his punishment takes in the real world. This shape is "absolutely" determined, only as an "approximation" of the negation of wrong underwritten by Abstract Right. This being so, Abstract Right cannot justify the shape that punishment takes in the real world. In order to justify the shape it takes and the shape it takes is that of various hard treatments -, we must justify the considerations that have led us to giving punishment this shape and no other. Pointing to a supposed "equality of value" between the criminal's act and his real-life punishment does not provide this justification. This is so, as Hegel himself clearly sees, because the shaping of punishments involves using our understanding to move beyond the limited guidance that the notion of equality of value equips us with. In deciding upon the shape of real-life punishments we therefore cannot but look towards "the various considerations which are relevant to punishment as a phenomenon" - and these include both punishment's effect on the individual offender, and punishment's relation to other social goals. This, when we give punishment shape, is the context in which these considerations are, as Hegel puts it, "of essential significance” ( $P R$, § 99 (Remark); see also § 214 (Addition) to the same effect). And we have not justified the very things that we do to an offender by way of punishment, the shape that his punishment takes, until and unless we have accounted for the "shaping considerations" of punishment.

\section{How punishment makes itself felt: Permissible and impermissible forms of punishment}

There are, however, certain limitations on permissible "approximations" that can be developed from Hegel's argument when it proceeds beyond the framework of Abstract Right.

Most serious punishments reach the will via imposing restrictions on the body - and Hegel explicitly argues that an attack on the body is in truth an attack on the will:

“[B]ecause I am alive as a free entity within my body ... this living existence may not be misused as a beast of burden. ... I am free for the other only insofar as I am free in my existence ... Violence done to my body by others is violence done to me". ( $P R, \S$ 48 (Remark)) 
There can be little doubt that the infliction of physical injury and pain counts as violence done to a person through his body. Whether imprisonment counts as "violence done to my body" is less clear. In the quoted passage, Hegel is concerned to address the sense in which we are free in our bodies. He attacks the sophistry of making "a distinction whereby ... the soul is neither touched nor affected if the body is abused and the existence of the person is subjected to the power of another” ( $P R, \S 48$ (Remark)). While I may inwardly withdraw myself from my existence, and in this sense "be free even if I am in chains", for others - that is, as a human being in a shared world - "I am in my body" (ibid.). Imprisonment, which is first and foremost a restriction of my freedom of movement and choice of company, although its conditions also have a direct effect on my bodily existence and comfort through making me dependent on the food, clothing and shelter that my place of confinement provides, subjects my existence to my captor's power. For this reason it would, from a Hegelian perspective, have to count as a form of violence done to me.

Within a Hegelian framework, it is also possible to get to my will without doing violence to my body. Recall that my will actualises itself by taking possession of objects, by making things mine. Hence my will can also be injured by taking my belongings away from me. The imposition of fines, which forces me to part with some of my possessions, and also the confiscations of objects of property are, thus, punishments that reach my will. ${ }^{75}$

To what extent does Hegel's theory allow for these various modes of injuring the will as forms of punishment? As we reach Morality, the subjectivity of the agent needs to be taken into account in determining the shape and impact of penal sanctions. This has one particularly important implication: arguably, it cannot conceivably be one's duty to submit to one's own destruction as a finite human being. The subjectivity of the agent cannot accept such a thing.

The basis for this argument is $P R, \S 127$, where Hegel observes that "The particularity of the interests of the natural will, taken together as a simple totality, is personal existence as life." Hegel then suggests that losing one's life is "an infinity injury to existence with total loss of rights." In the context of $\S 127$, this is his argument for entitling the agent to a right of necessity when this interest is in conflict with the mere finite interests of others. This right of necessity is not exhausted by securing one's own physical survival. Hegel connects the right to preserve one's life by whatever finite violations necessary in cases of immediate emergence with the recognition of another moral entitlement of, one may imagine, great practical significance:

"From this right of necessity arises the benefit [of need], whereby a debtor is permitted to retain his tools, agricultural implements, clothes, and in general as much of his resources - i.e. of the property of his creditors - as is deemed necessary to support him, even in his accustomed station in society." $(P R, \S 127)^{76}$

The Addition to $\S 127$ records that the "beneficium competentiae" is of relevance "because links of kinship and other close relationships entail the right to demand that no one should be sacrificed completely for the sake of right.” The immediate context of this discussion is, of course, a civil judgment (and hence an obligation that within the Hegelian scheme has not

\footnotetext{
${ }^{75}$ I thank Jeremy Horder for pressing me to explain the status of fines in Hegel's theory.

${ }^{76}$ The "beneficium competentiae" refers to "certain provisions deriving from Roman law, [which ensured that] a debtor or unsuccessful defendant in a civil action could not be required to pay more than his means permitted (...); for example, he could not be deprived of the tools necessary to ply his trade.” (Hegel 1821/1991, Editorial note 2 to $\S 127$, p. 425). Schild (1989b, p. 153) points out that, as an institution of positive law, the "beneficium competentiae” belongs to the sphere of civil society.
} 
arisen from a criminal wrong but from a lesser kind of wrong), but for the substantive argument made, this difference does not seem to matter. Hegel's discussion in $\$ 127$ is concerned with the right of subjectivity, ie with the rights of agents as self-determining, finite human beings - and there is no suggestion anywhere in Hegel's philosophy that this dimension or aspect of human existence may be ignored in the context of punishment. To the contrary: one would expect it to be carried over into the next sphere (of civil society), where political duties become visible. Hegel's colleague and editor, Eduard Gans, certainly applied this limitation to the context of punishment, arguing that, while fines are permissible, confiscation of D's entire property is not: “Confiscation cuts off a man's shadow, takes something of his humanity away from him. To take away someone's entire property is to deprive him of the capacity for self-determination, in other words his freedom."

The right of necessity appears to rule out the death penalty as a sanction that we could ever impose on a person, since imposing it clashes with that person's right to preserve his life against extreme danger. Modern commentators have indeed argued that this is the case, ${ }^{78}$ but this analysis sits uneasily with Hegel's assertion, as recorded by Hotho, that "although retribution cannot aim to achieve specific equality, this is not the case with murder, which necessarily incurs the death penalty” ( $P R, \S 101$ (Addition)). It does not appear to have occurred to Hegel's contemporaries to question the death penalty's compatibility with the right of subjectivity and to conclude on this basis that Hegel could not, coherently within his system, support it. In Gans's published lectures, which were openly built on Hegel's Philosophy of Right and in which Gans offers lengthy discussions of the forms that punishment may, or may not, take, Gans considers the death penalty permissible and indeed necessary with an argument that closely matches the quotation given above from Hotho's lecture notes. ${ }^{79}$ It appears to me that we can do little more here than note the tension between the position of abstract right, where infinite injury (to the will) appears insufficiently matched by a mere finite injury inflicted in response, and the right of subjectivity, which cannot allow infinite injury (now, to one's life) and always retains the right to resist it. This tension exists because Hegel's philosophical approach leaves no room for any notion of rights forfeiture. Rights cannot be forfeited simply because at the point where they are forfeited, they are lost and the Philosophy of Right is built on the contrary premise that everything we do to each other we do embedded in a framework of right, as a realisation of our freedom. ${ }^{80}$ Perhaps the best way of resolving the tension is to argue that the retributive principle of abstract right might indeed suggest that infinite injury can only be matched by an injury that is, likewise, infinite, but that the right of subjectivity stands in the way of the legitimate imposition of this retribution notwithstanding. ${ }^{81}$

If this argument is accepted, we can see a more general limitation for legal punishment take shape: an injunction against the imposition of life-destroying punishments of any kind, including those that deprive the offender of the prospect of leading a meaningful life and of preserving the means of his future livelihood, not only sanctions that deprive him of his right to preserve his own physical existence as such. So to this extent we have an account of

\footnotetext{
${ }^{77}$ Gans 1833/2005, p. 118 (my translation).

${ }^{78}$ See eg Hogan 2014, Caspers 2012.

${ }^{79}$ Gans 1833/2005, p. 118.

${ }^{80}$ I thank Matt Kramer for suggesting that I clarify this point.

${ }^{81}$ Some modern commentators dismiss the remark quoted in the text on the basis that it was not included by Hegel in his published text but is taken from the lecture notes of his students (see eg Dubber 1992, pp. 1589-90). If this reasoning is meant to throw into doubt that Hegel really did make this point in his lectures, then the argument is weak. The same point already appears in Wannenmann's notes, taken during 1817-18 (LNR, § 113); there can in my view be little doubt that Hegel regularly made this point in his lectures. That Hegel was nevertheless uncomfortable with the death penalty is borne out by the fragment discussed below.
} 
legitimate forms of penal sanctions that takes us (still within Hegel's framework) somewhat further that Hegel himself cares to do. ${ }^{82}$

This limitation still leaves us with a range of punishments that can cause considerable unhappiness and pain to the person undergoing the punishment. Does their suffering disrespect them as persons? The answer to this question appears to depend on the relationship that suffering has to the will. Suffering is a wide notion. While it always connotes prolonged pain, it differs greatly in magnitude and in the responses it leaves open to the person who undergoes it. Whether suffering disrespects the person appears to be a function of how bad the suffering is for the individual - whether it reduces the individual to his animal self where his consciousness is entirely filled by his pain, or whether it is something the individual can still inwardly get some distance from such that he can make a decision about how to relate to it. Will-destroying suffering is certainly incompatible with the idea of punishment as an honourbestowing recognition of personhood. It destroys what makes the person a person. When the suffering incidental to the punishment is less intense, such that an offender can still "withdraw from [his] existence" and "make it external to [him]" (PR, § 48 (Remark)), the position is less clear-cut. It is then up to the offender whether to shut himself off against it or to identify with his suffering as his punishment. Provided that the suffering does not reach the intensity of overwhelming and relentless physical pain that would preclude an individual's having a choice about how to relate to his suffering, it is arguable that the suffering induced by the punishment does not disrespect the offender as a human being, since he can undergo it with his sense of self intact.

This argument, however, overlooks the intersubjective or communicative aspect of punishment. Recall how Seelmann pinpointed the significance of punishment's censuring recognition of personhood: that it marks an "ultimately positive orientation of the penalising agent towards the offender". ${ }^{83}$ This orientation is, arguably, lost when the penal agent sets out to make the penal subject suffer. With this concern in mind, let us turn to what the infliction of punishment means for the penalising agent.

\section{The penalising agent's relationship to the offender's suffering}

The subjectivity of the penalising agent is not addressed in the Philosophy of Right. Here, punishment emerges fully only as an already-institutionalised practice. Within Hegel's overall philosophy, this picture of punishment is arguably incomplete. To complete it, we have to attend to what responding to criminal wrongs by way of legal punishment has in common with responding to transgressions by the will more generally. The most exhaustive treatment of this latter question is found in the Phenomenology of Spirit (PS), in Hegel's discussion of the claims of conscience. ${ }^{84}$

What Hegel demonstrates in the Phenomenology is that (as Bernstein explains) "any significant action we perform either potentially or actually transgresses the possibility of prospective justification" ${ }^{85}$ since it stems from our conscience which, by definition, must claim but cannot know that what it perceives to be the right action, is, indeed, morally right.

\footnotetext{
${ }^{82}$ Similar Zabel 2011, p. 147 (suggesting that the field of normative communication that Hegel establishes through the connections between the will of socially embedded actors provides the foundation and the logic for determining the ground and measure of punishment).

${ }^{83}$ Seelmann 2014, p. 115.

${ }^{84}$ In this sub-section, I draw heavily on J.M. Bernstein's masterful discussion of the dynamics of conscience (in Bernstein 1996). I thank Liat Levanon for drawing my attention to Bernstein's work.

${ }^{85}$ Bernstein 1996, p. 52.
} 
Hence transgression is ubiquitous, and we as humans have to work out a way of relating to each other through, and after, transgression, such that we can move forward. What conscience does when the possibility of a past transgression is raised, is to confess to the action - which is not, as such, also an admission of transgression. It simply throws the confessor's claim to have acted rightly (and his admission of the contingency built into that rightness-claim) open to response. ${ }^{86}$ That response, by the violated party, will often be a non-responsive, hardhearted one: a contrasting of "the beauty of its own soul with the penitent's wickedness" which "confronts the confession of the penitent with his own stiff-necked unrepentant character, mutely keeping himself to himself and refusing to throw himself away for the other” (PS, § 667; quoted in Bernstein, p. 48). And this response, as Bernstein points out, is "internally well motivated. You have transgressed upon me and I have been injured. My injury, my hurt and pain and anger, are what turn me away from you, lock me within myself. ... The injured self is hence as captured by its injury as the confessing self was trapped by her deed." ${ }^{87}$ But that leaves us in a dilemma when we come to "understand that there is nothing we can $d o$ with our injury, any more than the transgressor could herself repair what she had broken. And yet, remaining within our injured sense of self disables us from going on (...)”, 88 Eventually, this realisation forces us towards engagement with the perpetrator. The new beginning lies in "an act of recognition through which, by releasing the transgressor from her deed I release myself from my hurt." ${ }^{89}$ In this perspective, human action - and human life unfolds in the ever-repeated rhythm of transgression-confession-forgiveness.

Another commonality between the general response to transgression and legal punishment becomes visible when we ask what inflicting the punishment might reveal about the penal agent. In Hegel's retelling of the conflict between Creon and Antigone, Creon's insistence on enforcing the law against Antigone is revealed as another subjective claim to rightness; "the belief by the hard heart [Creon's unresponsive reaction to Antigone's confession] that it occupies the place of universality is illusory." ${ }^{90}$ But if this is so, then the punishing agent, in punishing, discovers something unpleasant about itself: it discovers what Hegel calls its hard heart, its motivation in self-assertion through revenge. ${ }^{91}$ There is no punishment in which the punishing agent does not take a stance, does not involve itself through the act of punishing in an ongoing struggle for recognition. A position of unengaged neutrality from which the punishment of transgressors merely "unfolds" as an application of a universal penal law is logically unattainable. To punish means to engage with the offender, and that means that it can and must always be asked what treating the offender in this or that way says about yourself.

This analysis, then, turns our attention to the commonality of all action - its potentially transgressive character. In that perspective, the criminal wrong does not stand apart. It is indeed a particularly serious wrong, because the transgression is a deliberate, not merely a risked, one - an act in which the denial of right is made manifest. Yet it confronts us with the same basic problem as other, non-deliberate, transgressions: we need to find a way to mend the tear in the structure of our social world that this act has caused. In this perspective, punishment occupies the same conceptual space as forgiveness, in that it is concerned with

\footnotetext{
${ }^{86}$ See Bernstein 1996, pp. 39-41, 44-46 for these claims of conscience. (In an attempt to capture Hegel's usage, Bernstein defines an act of conscience as "any non-routine, significant human action” (p. 36)).

${ }^{87}$ Bernstein 1996, p. 61.

${ }^{88}$ Bernstein 1996, p. 61 (emphasis original).

${ }^{89}$ Bernstein 1996, p. 62.

${ }^{90}$ Bernstein 1996, p. 61.

${ }^{91}$ I thank Liat Levanon for suggesting this point to me.
} 
"the same end ... namely, a putting an end to a course of action and thereby mending the fabric of society by immediately (through punishment) reintegrating the criminal into it." ${ }^{2}$

This brings us back to the link Seelmann draws between punishment, honour, and recognition: in recognising the personhood of the offender, punishment can be said to involve a positive stance of the penal agent towards the offender. But not all punishment expresses such a positive orientation. The connection is not intrinsic but contingent upon the attitude that the penal reaction, in fact, instantiates. If punishment is "detached from the effort of repairing the rent in society and returning the criminal to it, [it] collapses into revenge." 93 If punishment strives to hurt, to make the punished person "really suffer", then it may well be an expression of the hard heart's stance that it is different from, and better than, the criminal - that there is no humanity we have in common. We should, for this reason, be suspicious of ourselves when we allow a desire to make the criminal suffer to express itself in the infliction of punishment.

Law, of course, claims to represent the "injured universal”; a claim made plausible by law's institutionalisation. As such, law claims to have transcended the subjectivity residing in the injured party's response. While this is a claim Hegel defends in the Philosophy of Right, it cannot isolate law enforcement against concerns that stem from the subjectivity of the penal agent. It may be a different subjectivity we now encounter - the subjectivity of an "aggrieved public" - but this subjectivity can still find expression in a punitive impulse that shares much with the injured party's hardened stance. In our actual social world, punishment and selfrighteousness, and punishment and cruelty, sit perilously close together. Hegel was well aware of the corrupting influence that punishment can have on the punisher, warning against the "moral lustfulness of punishing others", and welcoming the abolition of physical punishments, such as whipping, directly aimed at causing pain and suffering through the body. ${ }^{94}$ He even had his reservations about imprisonment, which he thought might easily go beyond the legitimate communicative isolation of the criminal from the community and reach over into sanctimonious and cruel attempts to remake him as a different individual. ${ }^{95}$ Punishment can be an act of recognition only if it treats the offender as a participant in a process where he and his response matter to the overcoming of his crime. It may not reduce him to an object in which, whether out of a desire to make him suffer, or out of false benevolence, all that is manifested is our power to do with him as we think fit.

\section{Punishment, human fallibility, and political obligation}

In thinking through how we, the public, relate to offenders through the institutions of law, we also need to come back to a feature of these institutions that we have so far only mentioned but not yet systematically addressed: the fact that anyone punished by our institutions of criminal justice is punished in the "realm of finite things" - a realm where our understanding must impose increasing restrictions on the determination of punishment in terms of an equality of value ( $P R, \S 101$ (Remark)), and where we can in any case only ever achieve an approximate fulfilment of this requirement. If real-life penal sanctions can therefore, in any event, only be approximations of justice, then they must be justified also in their dimension as approximations; as political choices we have made. In essence, this is a constitutional issue. It goes to the status of the individual as a legal subject in the political sense - as someone who falls under the authority of the law and is expected to obey it, notwithstanding that many of

\footnotetext{
92 Bernstein 1996, p. 57.

${ }^{93}$ Bernstein 1996, p. 58.

${ }^{94}$ Schäfer 2014, text at note 317.

${ }^{95}$ Schäfer, ibid. (with references from Hegel's writings).
} 
the law's impositions on him are no more than contingent determinations arrived at through philosophically radically underdetermined political processes.

The crucial characteristic of the "realm of finite things" is that it is also a realm of human, and institutional, fallibility. This is so for three reasons: (1) legal entitlements most be provable and proven, and such proof may fail where, if the true facts were proven, the law would be on the losing party's side (cf $P R, \S 222 ; \S 222$ (Addition)); (2) specific determinations must be made in the application of law to individual cases, and this must - due to the limited degree of specificity achievable in law's rules - be done by judges whose decisions then necessarily include a degree of arbitrariness (in a modern formulation, we might say that Hegelian "right" and its posited law underdetermine the outcome of particular cases) (cf $P R, \S 214 ; \S 216$; § 227); and (3) facts may be found against the denial of one party, or against the denial of these facts by a defendant in a criminal case (cf $P R, \S 227$ (Addition)). In short, our real-world administration of justice is shot through with contingency and error.

The institutional designs we have are (to Hegel) the best that can be devised to limit the impact of these contingencies. In particular, law cannot hope to pre-empt the need for further determinations to be made in the process of its application $(P R, \S 214)$, or to remain static over time ( $P R, \S 216)$. Contingencies of fact-finding become more palatable to those who have to seek their right in court when they have reason to place "confidence ... in the subjectivity of those who arrive at the verdict [on the facts]" (as being of their own kind) ( $P R$, $\S 228$, read together with $\S 227)$. Yet, quite obviously, this does not make these institutions infallible, only just and necessary despite their fallibility.

As a "member of civil society", we not only have the "right to stand in a court of law" but "also the duty to submit to the court's authority and to accept its decision alone when [our] own right is in dispute” $(P R, \S 221),{ }^{96}$ and if this is so notwithstanding the fallibility of these institutions, then the impact court decisions may have on our right of subjectivity - on our finite lives and vulnerable selves - must be limited so as to avoid the complete destruction of our real freedom. This is, indeed, an implication of the right of subjectivity that Hegel already raised explicitly in his discussion of the right of necessity (in $P R, \S 127$ ). In the sphere of Morality, this right has nothing to do with the fallibility of judgment. It is the right of those who are really in debt to their creditors, whose lives may be at risk entirely due to their own fault. When we return to the point in the context of Ethical Life, though, we see that it matters also because it safeguards us against the catastrophic impact of contingency. In the sphere of civil society, we can see an additional reason why we must limit the consequences of the enforcement of law on its human subjects: that being subject to law means also being subject to an ineradicable risk of being convicted and punished despite being innocent.

Though Hegel does not use this terminology, undergoing court-imposed punishment in the sphere of civil society becomes one's political duty. Whereas for a Rawlsian and a Contractarian the duty to submit to state punishment (to the extent that such a duty is recognised at all) is "political” all the way down, for Hegel this duty has, in part, pre-political origins. It emerges as a political duty through a process of evolution - but, importantly, also transformation. So what emerges as a political duty is not too dissimilar from the contractarian result. In particular, once we have reached state punishment in the Hegelian model, we no longer rely (even in this model) on "a conception of punishment as necessitated

\footnotetext{
${ }^{96}$ Cf also $P R$, $\$ 219$ (Remark): “The administration of justice [whatever its historical origins, which may well lie in patriarchal relationship, or in coercion] should be regarded as both a duty and a right on the part of public authority, and as a right, it is not the least dependent on whether individuals choose to entrust it to an authority or not.”
} 
by wrongdoing" - the kind of conception that Melissaris rightly argues is ruled out for a liberal theory. ${ }^{97}$ Instead, we rely on a conception of punishment as a validation of the normative order and (as Johnson put it) the recognitive structure of society. ${ }^{98}$

It is only through conceiving of these duties as political duties that we can explain why we have to submit to an imperfect system of potentially unjustified penal and other impositions. But this then also means that the shape of these duties must be such that they cannot demand of us too much sacrifice - as they must be duties that must be justifiable even on the assumption that they will sometimes be enforced against someone unjustifiably. If we know that our practices will involve punishment sometimes being imposed on those who have been found guilty in error, the political duty of all of us to submit to non-appealable ("validly authorised") punishments can only endorse punishments that are not life-trashing ${ }^{99}$ - because living in a polity that practised life-trashing sanctions would turn us into Russian roulette players. ${ }^{100}$ It would for this reason not be a political community that would deserve our allegiance.

This gives rise to a second point: do our political duties possibly include submitting to lifetrashing sanctions if we are indeed guilty of having committed a wrong that has ruined another, innocent person's life? - Hegel's explanation of why people, in truth, feel indignation at the imposition of the death penalty even on someone they believe to be guilty, suggests that this may not be so. ${ }^{101}$ Why, asks Hegel, would "a multitude of public and at once cruel executions [make] the character of the people savage and indifferent to such punishment, as also to crime itself", and thus "[bring] about precisely the opposite of the end which legislators and judges had in mind in the matter of public punishment"? It cannot, Hegel suggests, be the case that people are simply indifferent. No: it is that they feel "indignation upon seeing a defenseless man executed by, even worse, a superior number of armed men", an indignation which "fails to be transformed among the witnesses into rage only because the pronouncement of the law is sacred to them", but which this representation that justice is being done cannot suppress, and which taints, in the eye of the public, the hangman with dishonour because, servant of justice though he may be, he kills in cold blood a man whose very "right of defending himself for his life has been taken away from him". 102

\footnotetext{
${ }^{97}$ Melissaris 2012, p. 139.

${ }^{98}$ Johnson 2011, p. 160. For Jakobs, the maintenance (or affirmation) of the validity of the "negated" norm is the essential structural function of punishment for Hegel: "With this [negation of the negation], the normative order of society is reaffirmed: a movement/sequence has been performed that accords neither with a "punitur, que peccetur" nor with a "punitur, quia peccatum est”: the gaze is forward-looking, as with the "ne peccetur", but the point is not the prevention of further crime - a project which, taken seriously, is in many respects a totalitarian one - but the preservation of the validity of the norms.” (Jakobs 2004, p. 26; my translation).

${ }^{99}$ I owe the expressing "life-trashing sentences" to Simon Hallsworth, who used it to refer to life sentences with long minimum terms of imprisonment imposed on young men for participation in gang violence. I mean by this expression a sentence which, while intended to be restricted in the impact in has on a prisoner's future, makes it very difficult, if not impossible, for prisoners to retain their identity, given that this is strongly linked to a biographically coherent life-course.

100 This may well be one (not frequently perceived) reason why the innocence campaigns in the US have undermined the perceived legitimacy of the death penalty more than any argument about how the death penalty is unjustifiable even when imposed on the guilty.

${ }^{101}$ All quotations in this paragraph are taken from Hegel 1785-1831/2002, pp. 100-101 (Fragment No 13 on "Public Capital Punishment”).

${ }^{102}$ Admittedly, this may be no more than a hunch on Hegel's part. That it may not be far off its mark is suggested, to my mind at least, by Pillsbury’s description of his reaction upon being told, years after he followed the trial as an observer, of the execution of a prisoner who had been sentenced to death for such egregious physical violence against his four small children that it killed two of them and caused lasting injuries to a third. During the sentencing hearing the man's own history of victimisation at the hands of his parents was thematised, but the death penalty was imposed on him nonetheless. Pillsbury writes that, when his wife rang him to say the
} 
Hegel observes that it is this that makes the crucial difference between the executed and those who die in battle:

"The man who dies in battle can be pitied by us, but such death does not vex us like death by execution, for one who dies in battle has exercised his natural right to defend his life.”

The message that executions send, then, the message that undermines rather than reinforces the perceived legitimacy of the criminal justice system, is: We are the sort of people who do this thing to one another. This is what, as Hegel perceptively suggests, breeds the indifferent attitude to punishment and crime alike, and it should make our criminal justice systems stay well clear of the impositions of sanctions that speak very badly of the sort of people we are. ${ }^{103}$

\section{Conclusion: With Hegel towards Penal Minimalism?}

A political system that conceptualises punishment as a mark of recognition, while recognising also the claims of subjectivity that can be made by all of its members, including offenders, must impose significant restrictions on the forms that penal sanctions may take. In such a system, punishment must look towards the person who is punished. It must understand that being someone liable to punishment is just one dimension or fact about this person. Another fact is that person's subjectivity, that he has physical and psychological needs, personal goals, skills, projects, and a finite life-span. A third fact is that person's membership in civil society, which entitles him, also, to benefit from our shared concern to structure our social and institutional practices in such a way that we maintain the preconditions for ethical living for all. The legitimacy of the state resides in its capacity to provide the latter. It can do so because it is flexible. A fully developed state can offer victims of crime infinitely more than bare acts of retribution performed against offenders. The security and reassurance that it provides to its citizens owes at least as much to other institutional structures as it owes to the criminal justice system. A legitimate state can, and must, also offer offenders more than merely different ways of wrecking their lives. It is only when punishment means more than retribution, when it can be reintegrative both in its self-understanding and in its actual effects, that the claims of Abstract Right, that a wrong be negated by a second negation, and of Morality and Ethical Life, that we must relate to each other as embodied, vulnerable, finite human beings, can be reconciled in the institutional structures of our shared social world.

Thinking about what justifies penal hard treatment vis-à-vis real life offenders - embodied and socially situated humans exposed to the operations of a fallible human institution therefore leads us in the direction of punitive minimalism: to a sanctioning regime that never, in the course of carrying out the sentence, forgets that it is dealing with a real human being who is also still a member of this polity and this human community.

It is at this juncture that a defensible retributivism develops out of an abstract philosophical principle into an embedded penal theory for real polities - where to treat an offender as a human being involves very much more than just pointing out that he, as a rational human being participating in practices of mutual recognition, has implicitly endorsed the abstract

man had been executed, he was "surprised by my own reaction. I felt hollow and sick. I was certain [this man] deserved severe punishment, but not death. I could not say exactly why, though.” (Pillsbury 1998, p. viii).

${ }^{103}$ Hegel's concern here appears to be also with the dishonour involved in being subjected to certain forms of punishment. In his lectures given in 1817-18, he discusses executions in the context of demeaning punishments, and approves neither of hangings nor of the guillotine ( $L N R, \S 113)$. 
retributive principle through his acts. This defensible retributivism insists that we ask concretely to what this commits an individual human being in the real world. The answer leads us to the need to justify punishment as something that imposes pain and suffering, causes social disadvantage and damage to the life-chances of offenders, and must thus be acceptable to them as a non-disproportionate consequence of their criminal act. It is, and should be, acceptable to all only if it is and remains compatible with the offender's selfunderstanding also as an ordinary valuable and vulnerable human being, and relates to the offender in this capacity. 


\section{Bibliography}

Anderson, Jami L. 1999. Annulment retributivism: a Hegelian theory of punishment. Legal Theory 5: 363-388.

Angehrn, Emil 1977. Freiheit und System bei Hegel. Berlin: De Gruyter.

Becchi, Paolo 2011. Die Strafe als Versöhnung und die Strafzwecke bei Hegel. Ein kritischer Überblick. In Strafe - Warum? Gegenwärtige Strafbegründungen im Lichte von Hegels Straftheorie, ed. Andreas von Hirsch, Kurt Seelmann and Ulfrid Neumann, 87-95. Baden-Baden: Nomos.

Bernstein, J.M. 1996. Confession and forgiveness: Hegel's poetics of action. In Beyond Representation: Philosophy and Poetic Imagination, ed. Richard Eldridge, 34-65. Cambridge: Cambridge University Press.

Boonin, David 2008. The Problem of Punishment. Cambridge: Cambridge University Press.

Brooks, Thom 2004. Is Hegel a retributivist? Bulletin of the Hegel Society of Great Britain 25: 113126.

Brooks, Thom 2007. Hegel's Political Philosophy: A Systematic Reading of the Philosophy of Right. Edinburgh: Edinburgh University Press.

Brooks, Thom 2012. Hegel and the unified theory of punishment. In Hegel's Philosophy of Right, ed. Thom Brooks, 103-123. London: Blackwell.

Brudner, Alan 2009. Punishment and Freedom. A Liberal Theory of Penal Justice. Oxford: Oxford University Press.

Brudner, Alan 2011. A Reply to Critics of Punishment and Freedom. New Criminal Law Review 14: 495-517.

Caspers, Britta 2012. “Schuld” im Kontext der Handlungslehre Hegels. Hamburg: Felix Weiner.

Dubber, Markus Dirk 1992. Rediscovering Hegel's theory of crime and punishment. Michigan Law Review 92: 1577-1621.

Du Bois-Pedain, Antje 2011. Von der "moralischen Wollust des Strafens” oder: Strafgewalt ohne Staatsgewalt aus hegelianischer Sicht. In Strafe - Warum? Gegenwärtige Strafbegründungen im Lichte von Hegels Straftheorie, ed. Andreas von Hirsch, Kurt Seelmann and Ulfrid Neumann, 205232. Baden-Baden: Nomos.

Dudley, Will 2002. Hegel, Nietzsche and Philosophy: Thinking Freedom. Cambridge: Cambridge University Press.

Feinberg, Joel 1970. Doing and Deserving. Essays in the Theory of Responsibility. Princeton: Princeton University Press.

Flechtheim, Ossip K. 1963. Die Funktion der Strafe in der Rechtstheorie Hegels. In Von Hegel zu Kelsen: Rechtstheoretische Aufsätze, ed. Ossip K. Flechtheim. Berlin: Duncker \& Humblot.

Flechtheim, Ossip K. 1975. Hegel's Strafrechtstheorie. Reprint edn. (first published 1936). Berlin: Duncker \& Humblot. 
Gans, Eduard 1833/2005. Naturrecht und Universalgeschichte. Vorlesungen nach G.W.F. Hegel. Ed. Johann Braun. Tübingen: Mohr.

Hegel, G.W.F. 1785-1831/2002. Miscellaneous Writings. Ed. Jon Stewart. Various translators. Evanston, Illinois: Northwestern University Press.

Hegel, G.W.F. 1807/1977. Phenomenology of Spirit. Transl. by A.V. Miller. Oxford: Clarendon Press.

Hegel, G.W.F. 1817-18/2012. Lectures on Natural Right and Political Science. The First Philosophy of Right. Transcribed by Peter Wannenmann. Ed. Staff of the Hegel Archives. Transl. by J. Michael Stewart and Peter C. Hodgson. Oxford: Oxford University Press.

Hegel, G.W.F. 1821/1991. Elements of the Philosophy of Right. Ed. A. Wood. Transl. by H.B. Nisbet. Cambridge: Cambridge University Press.

Hegel, G.W.F. 1821/2000. Grundlinien der Philosophie des Rechts. Ed. E. Moldenhauer and K.M. Michel. 6th edn. Frankfurt/Main: Suhrkamp.

Hegel, G.W.F. 1830/1991. The Encyclopaedia Logic: Part I of the Encyclopaedia of Philosophical Sciences with the Zusätze. Transl. by F.F. Geraets, W.A. Suchting and H.S. Harris. Indianapolis: Hackett.

Hirsch, Andrew von 1993. Censure and Sanctions. Oxford: Oxford University Press.

Hogan, Brandon, 2014. From Punishment to Recognition: Toward a Hegelian Theory of Criminal Justice. PhD thesis, University of Pittsburgh. (http://d-scholarship.pitt.edu/20354/).

Honderich, Ted 1976. Punishment: The Supposed Justifications. Harmondsworth: Penguin.

Jakobs, Günther 2003. Der Zweck der Vergeltung. Eine Untersuchung anhand der Straftheorie Hegels. In Festschrift für Nikolaos K. Androulakis, ed. Leonidas Kotsalis, 251-269. Athen: Ekdoseis Ant. N. Sakkoula.

Jakobs, Günther 2004. Staatliche Strafe: Bedeutung und Zweck. Paderborn: Verlag Ferdinand Schöningh.

Jacobson, Jessica, Gillian Hunter and Amy Kirby 2015. Inside Crown Court: Personal Experiences and Questions of Legitimacy. Bristol: Policy Press.

Johnson, Jane 2011. Hegel on punishment: a more sophisticated retributivism. In Retributivism. Essays on Theory and Policy, ed. Mark D. White, 146-168. Oxford: Oxford University Press.

Klesczewski, Diethelm 1991. Die Rolle der Strafe in Hegels Theorie der bürgerlichen Gesellschaft. Eine systematische Analyse des Verbrechens- und Strafbegriffs in Hegels Grundlinien der Philosophie des Rechts. Berlin: Duncker \& Humblot.

Knowles, Dudley 2001. Hegel on the justification of punishment. In Beyond Liberalism and Communitarianism: Studies in Hegel's Philosophy of Right, ed. Robert R. Williams, 125-145. Albany: State University of New York Press.

Köhler, Michael 1987. Strafbegründung im konkreten Rechtsverhältnis: Die Aufhebung der abstrakten Straftheorie am Leitfaden der hegelschen Rechtsphilosophie. In Festschrift für Karl Lackner zum 70. Geburtstag am 18. Februar 1987, ed. Wilfried Küper, Ingeborg Puppe and Jörg Trenckhoff, 11-37. Berlin and New York: de Gruyter.

Mackie, J.L. 1982. Morality and the retributive emotions. Criminal Justice Ethics 1: 3-10. 
McDermott, Daniel 1999. The duty to punish and legitimate government. The Journal of Political Philosophy 7: 147-171.

Melissaris, Emmanuel 2012. Toward a political theory of criminal law: a critical Rawlsian account. New Criminal Law Review 15: 122-155.

Merle, Jean-Christophe 2003. Was ist Hegels Straftheorie? Jahrbuch für Recht und Ethik - Annual Review of Law and Ethics 11: 145-176.

Merle, Jean-Christophe 2009. German Idealism and the Concept of Punishment. Cambridge: Cambridge University Press.

Mertens, Stefan, 2008. Die juridische Vermittlung des Sozialen. Würzburg: Königshausen \& Neumann.

Mohr, Georg 1997. Unrecht und Strafe (§§ 82-104, 214, 218-220). In Klassiker Auslegen. G.W.F. Hegel, Grundlinien der Philosophie des Rechts, ed. Ludwig Siep, Berlin: Oldenbourg Akademieverlag.

Moyar, Dean 2011. Hegel’s Conscience. Oxford: Oxford University Press.

Neumann, Ulfrid 2011. Anfragen an Hegels Straftheorie aus „nachmetaphysischer“ Sicht. In Strafe Warum? Gegenwärtige Strafbegründungen im Lichte von Hegels Straftheorie, ed. Andreas von Hirsch, Kurt Seelmann and Ulfrid Neumann, 159-171. Baden-Baden: Nomos.

Norrie, Alan W. 1991. Law, Ideology and Punishment. Retrieval and Critique of the Liberal Ideal of Criminal Justice. Dordrecht/Boston/London: Kluwer.

Patten, Alan 1999. Hegel's Idea of Freedom. Oxford: Oxford University Press.

Pillsbury, Samuel H. 1998. Judging Evil. Rethinking the Law of Murder and Manslaughter. New York: New York University Press.

Primoratz, Igor 1989. Justifying Legal Punishment. Atlantic Highlands, New Jersey: Humanities Press.

Reyburn, Hugh A. 1921. The Ethical Theory of Hegel. A Study of the Philosophy of Right. Oxford: Clarendon Press.

Ristroph, Alice 2011. When Freedom Isn’t Free. New Criminal Law Review 14: 468-485.

Schäfer, Rainer 2014. Was Freiheit zu Recht macht: Manuale des Politischen. Berlin and New York: de Gruyter.

Schild, Wolfgang 1989a. Sittlichkeit als politische Gesinnung des Staatszutrauens. Hegel-Jahrbuch 1988: 158-169.

Schild, Wolfgang, 1989b. Hegel's Lehre vom Notrecht. In Die Rechtsphilosophie des deutschen Idealismus, ed. Vittorio Hösle, 146-163. Hamburg: Meiner.

Schild, Wolfgang 2004.The contemporary relevance of Hegel's concept of punishment. In Hegel on Ethics and Politics, ed. Robert B. Pippin and Otfried Höffe, 150-179. Cambridge: Cambridge University Press. 
Schild, Wolfgang 2011. Hegel's Theorie der Strafrechtsinstitutionen. In Strafe - Warum? Gegenwärtige Strafbegründungen im Lichte von Hegels Straftheorie, ed. Andreas von Hirsch, Kurt Seelmann and Ulfrid Neumann, 97-109. Baden-Baden: Nomos.

Seelmann, Kurt 2014. Does punishment honour the offender? In Liberal Criminal Theory: Essays for Andreas von Hirsch, ed. A.P. Simester, Antje du Bois-Pedain and Ulfrid Neumann, 111-121. Oxford: Hart Publishing.

Smith, A.T.H. 2015. Repositioning the law of contempt: the Criminal Justice and Courts Act 2015. Criminal Law Review 2015: 845-854.

Stillman, Peter 1976. Hegel’s idea of punishment. Journal of the History of Philosophy 14: 169-183.

Waldron, Jeremy 1992. Lex talionis. Arizona Law Review 34: 25-52.

Zabel, Benno 2011. Die Vernunft des Leviathan. In Strafe - Warum? Gegenwärtige Strafbegründungen im Lichte von Hegels Straftheorie, ed. Andreas von Hirsch, Kurt Seelmann and Ulfrid Neumann, 121-158. Baden-Baden: Nomos. 